\title{
CONFERENCIA
}

\section{ANUNCIO DE UN NUEVO RECURSO PARA LA ENSEÑANZA ONLINE DE LA HISTOLOGÍA, QUE ES PREFERIDA POR LOS ESTUDIANTES, OBTIENE MEJORES RESULTADOS Y REDUCE EL TRABAJO DOCENTE.}

\author{
Geoffrey T. MEYER \\ Escuela de Anatomía y Biología Humana, Universidad de Western Australia, Crawley, Australia.
}

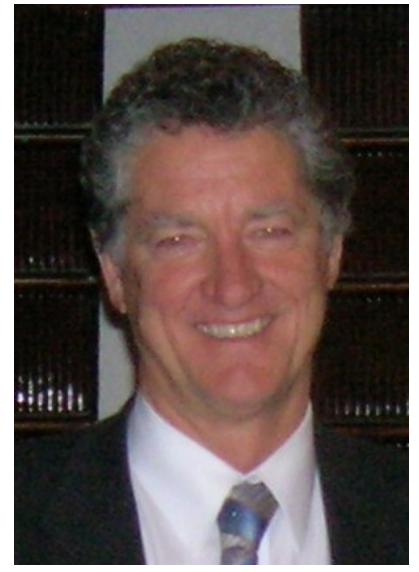

Introducción: La enseñanza de la histología es costosa, en especial en algunas universidades con recursos limitados 0 anticuados, tales como microscopios y colecciones de diapositivas inadecuados. El número creciente de estudiantes ha requerido la duplicación de clases prácticas. Las actividades prácticas incrementan la intensidad y las horas de trabajo de los docentes. Una presentación visual simulará cómo pueden los alumnos estudiar histología online.

Objetivos: Explicaré cómo la utilización de este recurso ha reducido la necesidad de los estudiantes de asistir a muchas sesiones prácticas de histología en laboratorio. Los alumnos ahora pueden estudiar histología satisfactoriamente en su propio tiempo - y que sea divertido!. No es necesario que los estudiantes tengan dirección académica por parte de los docentes para lograr los objetivos - aún en las clases prácticas!.
Material y Método: Podrán ver cómo los estudiantes interactúan con imágenes de alta calidad (6600) y señalan en textos vinculados para identificar los datos clave de las estructuras histológicas. Los estudiantes utilizan un microscopio computarizado para examinar las estructuras de tejidos/órganos con magnificación de diferentes grados. Muchas opciones proveen respuesta instantánea a los estudiantes, haciendo el aprendizaje de la histología eficiente y gratificante, y mejora significativamente las calificaciones de los estudiantes en los exámenes.

Resultados: Este sistema de aprendizaje apunta a las necesidades de aprendizaje auto-dirigido e independiente de los estudiantes y promueve el compromiso del estudiante y la efectividad del aprendizaje. Explicaré cómo la utilización de este recurso ha reducido la necesidad de nuestros estudiantes de asistir a muchas sesiones prácticas de histología y así, reducir la actividad docente y los costos del Departamento/Escuela proveyendo estas sesiones histológicas prácticas.

Usted tendrá la oportunidad de ver todos los contenidos e incluso personalizar el producto para su propio curriculum de histología.

http://histology-online.com 